\title{
Archeological Investigations of the Lang Pasture (41AN38) Midden Deposits on private property west of the SH 155 Right-of- Way, Anderson County, Texas
}

Timothy K. Perttula

Heritage Research Center, Stephen F. Austin State University

Bo Nelson

Heritage Research Center, Stephen F. Austin State University

Mark Walters

Heritage Research Center, Stephen F. Austin State University

LeeAnna Schniebs

Follow this and additional works at: https://scholarworks.sfasu.edu/ita

Part of the American Material Culture Commons, Archaeological Anthropology Commons, Environmental Studies Commons, Other American Studies Commons, Other Arts and Humanities Commons, Other History of Art, Architecture, and Archaeology Commons, and the United States History Commons

Tell us how this article helped you.

This Article is brought to you for free and open access by the Center for Regional Heritage Research at SFA ScholarWorks. It has been accepted for inclusion in Index of Texas Archaeology: Open Access Gray Literature from the Lone Star State by an authorized editor of SFA ScholarWorks. For more information, please contact cdsscholarworks@sfasu.edu. 
Archeological Investigations of the Lang Pasture (41AN38) Midden Deposits on private property west of the SH 155 Right-of-Way, Anderson County, Texas

\section{Creative Commons License}

\section{(c) (1) \&}

This work is licensed under a Creative Commons Attribution-NonCommercial 4.0 International License 


\title{
Archeological Investigations of the Lang Pasture (41A N38) Midden Deposits on private property west of the SH 155 Right-of-Way, Anderson County, Texas
}

\author{
Timothy K. Perttula, with contributions by Bo Nelson, \\ Mark Walters, and LeeAnna Schniebs
}

\section{INTRODUCTION}

In the spring of 2006 data recovery investigations were completed at the Lang Pasture site (41AN38) by Coastal Environments, Inc. (Baton Rouge, Louisiana) and Archeological \& Environmental Consultants, LLC (Austin and Pittsburg, Texas) for the Texas Department of Transportation. The site is situated along the SH 155 rightof-way in the Caddo Creek basin in northeastern Anderson County, Texas, in the Caddo archeological area of Northeast Texas (Perttula et al. 2005; Kelley et al. 2006). The archeological excavations indicate that the site was primarily occupied by Caddo peoples during the Frankston phase, sometime after A.D. 1400. The number and kinds of features identified in the right-of-way - portions of two circular structures, two possible ramadas or work platforms, several large pit features, and a number of extended burials with associated funerary offerings-indicate that the Lang Pasture site is likely a domestic farmstead occupied by more than 1-2 families. Most of the site occurs outside the right-of-way on private property.

At the time of the data recovery work, Bo Nelson and Mark Walters noted dark midden-stained sediments in gopher mounds ca. 8-15 m west of the 4-5 m wide right-of-way (ca. N189 E184 on the 41AN38 right-of-way grid, see Kelley et al. 2006: Figure 2-1), but on private property. Since no midden deposits had been identified (and were never identified) in the SH 155 right-of-way, despite extensive excavations, we felt it was important as part of a better and broader understanding of the archeological record at the Lang Pasture site (41AN38) to investigate the midden to establish its content, age, and overall extent. Permission was obtained from the private landowner, Mr. Earl Lang, to carry out a limited amount of work, and this work was done in March 2006. This article presents the results of the archeological investigations at these prehistoric Caddo midden deposits.

\section{Field Investigations}

Six shovel tests (ST 1-6) and a 50 x $50 \mathrm{~cm}$ unit (ST 7) were excavated in and around the midden deposits. The midden is approximately $10 \mathrm{~m}$ in diameter, and in its center (ST 1), the very dark grayish-brown (10YR 3/2) loamy sand sediments were approximately $30 \mathrm{~cm}$ thick, and overlay a yellowish-red (5 YR 5/8) loamy fine sand that extended to at least $60 \mathrm{~cm}$ below the surface (bs). Small amounts of ash were noted in ST 3 (20-40 $\mathrm{cm}$ bs) and ST 7 (20-40 cm bs).

Five of the six shovel tests turned out to be within the midden, and the midden deposits ranged from $23-30 \mathrm{~cm}$ in thickness away from its center. ST 6 was outside the midden, and had dark yellowish-brown (10YR 4/4) 
loamy fine sand sediments from at least $0-40 \mathrm{~cm}$ bs. In ST 7 (placed $1 \mathrm{~m}$ west of ST 1), the midden deposits are approximately $44 \mathrm{~cm}$ in thickness.

The ST 7 excavations also exposed parts of two cultural features. The first (Stain 1) is more than $50 \mathrm{~cm}$ in diameter, and appears to be a pit feature; it extended to $66 \mathrm{~cm}$ bs. Stain 2 is $16-18 \mathrm{~cm}$ in diameter, and is probably a post hole. Its bottom depth was $65 \mathrm{~cm}$ bs. The occurrence of cultural features in and below the midden suggests that the midden may have accumulated over (or in?) an abandoned prehistoric Caddo structure that stood west of the two other Caddo circular domestic structures in the SH 155 right-of-way. Small flotation samples were taken of the fill from both stains, and animal bone, burned clay, and ceramic sherds were relatively common in the fill of both of them. Charred nutshells and other charred plant remains are present in Stains 1 and 2, but they have not been studied at this time.

\section{Recovered Material Culture Remains}

A relatively large number of prehistoric material culture remains, as well as animal bone, have been recovered in the very limited investigations at the Lang Pasture (41AN38) midden (Table 1). In the apparent heart of the midden (i.e., ST 1 and ST 7), artifact densities are ca. 170-190 per $\mathrm{m}^{2}$, while outside the midden (i.e., ST 6), the densities are much lower: only ca. $40 \mathrm{per}^{2}$. In other shovel tests in the midden, the artifact densities range from ca. 40-80 per $\mathrm{m}^{2}$ (see Table 1).

The material culture remains from the midden are dominated by plain and decorated ceramic sherds from Caddo ceramic vessels. Not including the animal bone (which accounts for $48 \%$ of all the artifacts found in the midden investigations), sherds comprise $74 \%$ of the recovered material culture artifacts, followed by lithic debris (17\%), burned clay (7\%), a ceramic elbow pipe sherd, and an unusual ceramic object discussed in more detail below.

The ceramic sherds are from vessels tempered primarily with grog (crushed sherds), with a small number having had burned bone added to the paste as temper. The use of bone temper is minimal in prehistoric and early historic Caddo ceramic assemblages in the upper Neches River basin (see Perttula et al. 2005: Table 1), generally less than $5 \%$ in any one assemblage.

The plain/decorated sherd ratio (P/DR) for the small sample from the Lang Pasture (41AN38) midden is 0.88. This is consistent with a Group II Frankston phase age for the midden deposits, based on a still developing seriation of decorated Caddo ceramic sherds from the area (see Perttula et al. 2005: Table 1). Group II Frankston phase sites are estimated to date sometime after ca. A. D. 1450 but before ca. A.D. 1600 or thereabouts. Since the P/DR value in assemblages seems to decreases towards 0.10 the younger the ceramic assemblage is (i.e., in historic Allen phase Caddo sherd assemblages, the P/DR has been documented to be at about 0.20 to 0.30 from several sites), the P/DR of 0.88 also suggests that the midden may have accumulated relatively late in the overall occupation of the Lang Pasture site (41AN38), because the P/DR from the test excavations in the SH 155 right-of-way (Lohse et al. 2004) is a higher 1.98 (falling in the Group III Frankston phase).

The decorated sherds are dominated by those that are brushed. There are 35 parallel brushed body sherds, two vertical brushed Bullard Brushed rims (Figure 1c) and one horizontal brushed rim, two parallel brushed-tool punctated body sherds (with the tool punctations in a row above the brushing, see Figure 1d), and one brushedappliqued body sherd (i.e., parallel brushing on either side of an appliqued fillet). All together, $82 \%$ of the sherds in the Lang Pasture (41AN38) midden decorated sherd sample have some form of brushing decoration on them. Other decorated utility wares in the assemblage include two sherds with rows of tool punctations on the vessel (see 
Table 1. Recovered artifacts from the 41AN38 midden.

\begin{tabular}{lllllllll}
\hline Provenience & PS* & DS & BC & Pi & LD & AB & Other & N \\
\hline Surface & 5 & 5 & & & & & & 10 \\
ST 1, 0-20 cm & 4 & 6 & & & 3 & 2 & & 15 \\
ST 1, 20-40 cm & 1 & 5 & & & 1 & 8 & & 15 \\
ST 1, 40-60 cm & 2 & 2 & & & & 2 & & 6 \\
ST 2, 0-20 cm & 1 & 4 & & & 1 & 1 & & 7 \\
ST 2, 20-40 cm & 1 & & & & & 2 & & 3 \\
ST 3, 0-20 cm & 2 & 1 & & & & 1 & & 4 \\
ST 3, 20-40 cm & 6 & & & & 1 & 4 & & 11 \\
ST 4, 0-20 cm & 1 & & & & 1 & 4 & & 2 \\
ST 4, 20-40 cm & 1 & 1 & & & 2 & 3 & & 9 \\
ST 5, 0-20 cm & 2 & 2 & & & 1 & 1 & & 2 \\
ST 5, 20-40 cm & & & & & 3 & & & 3 \\
ST 6, 0-20 cm & & & & & & & & 2 \\
ST 6, 20-40 cm & 2 & & & & 3 & 9 & & 23 \\
ST 7, 0-10 cm & 4 & 5 & 2 & & 1 & 8 & & 16 \\
ST 7, 10-20 cm & 2 & 5 & & & 1 & 9 & & 15 \\
ST 7, 20-30 cm & & 4 & 1 & \multirow{2}{*}{1} & 1 & 19 & & 26 \\
ST 7, 30-40 cm & & 5 & & & & 19 & & 26 \\
ST 7, 40-50 cm & 6 & 1 & & & 1 & 13 & & 22 \\
ST 7, Stain 1 & 2 & & 6 & & 1 & 13 & 1 & 21 \\
ST 7, Stain 2 & 2 & 4 & & & & & \\
\hline Total & 44 & 50 & 9 & 1 & 22 & 118 & 1 & 245 \\
\hline
\end{tabular}

$\mathrm{PS}=$ plain sherd; $\mathrm{DS}=$ decorated sherd; $\mathrm{BC}=$ burned clay: $\mathrm{P}=$ =pipe; $\mathrm{LD}=$ lithic debris; $\mathrm{AB}=$ animal bones

Figure 1e), and three sherds with straight or diagonal incised lines, the latter decoration being on a jar rim sherd.

Only four of the sherds (8\%) are from engraved fine wares. One of these has horizontal engraved lines, while another has broad curvilinear lines (see Figure 1b) with a red pigment smeared in the engraved lines. This sherd is probably from a Poynor Engraved vessel (see Kleinschmidt 1982: Figure 19), as is another sherd (ST 7, 10-20 $\mathrm{cm})$ that has part of an engraved negative oval. Finally, there is a Patton Engraved body sherd from ST 7 (0-10 $\mathrm{cm}$ ) (see Figure 1e). It has large triangular tick marks pendant from a horizontal engraved line.

There is a plain elbow pipe rim sherd from ST 7 (30-40 cm bs). Similar elbow pipe sherds-both from plain and decorated elbow pipes - have been recovered from excavations at the Lang Pasture site (41AN38) in the SH 155 right-of-way (Kelley et al. 2006).

The one unusual clay object is from Stain 2 in ST $7(50-58 \mathrm{~cm}$ bs). It is flat and smoothed on one side, and 


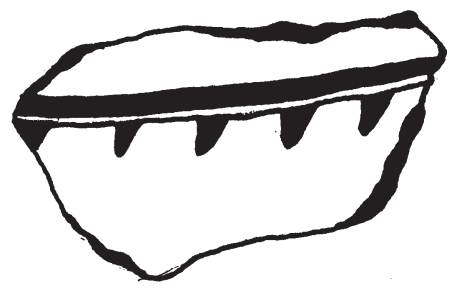

a

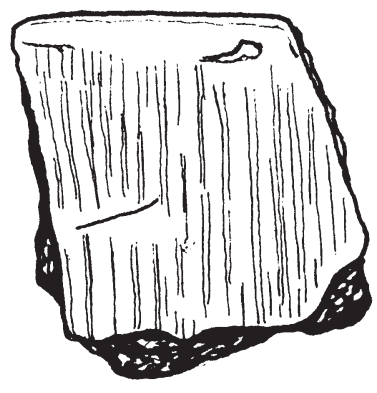

c
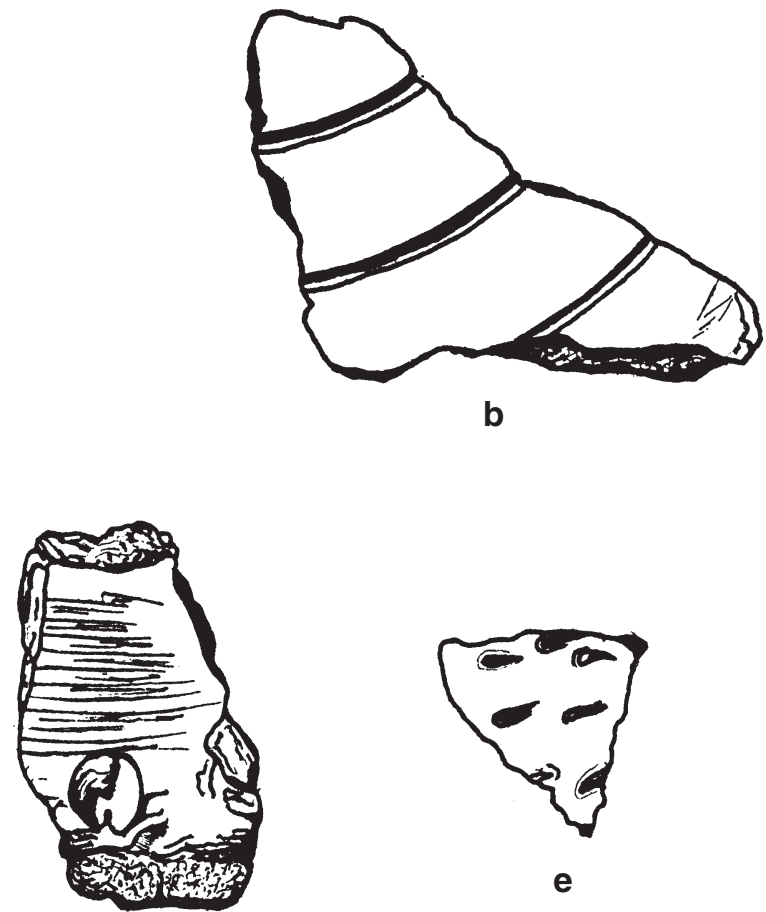

e

d

Figure 1. Decorated sherds from the Lang Pasture (41AN38) midden: a, Patton Engraved; b, curvilinear engraved; c, vertical brushed; d, brushed-tool punctated; e, tool punctated. Provenience: a, ST 7, 0-10 cm; b, ST 1, 20-40 cm; c, ST 1, 0-20 cm; d, ST 7, 30-40 cm; e, Surface. Drawings by Bobby Gonzalez.

noticeably conical-shaped and roughened on the other. I interpret this fired piece of clay as some sort of clay plug, perhaps to insert in the opening of a seed jar or a similar kind of vessel.

The nine pieces of burned clay are all from ST 7 (see Table 1). These pieces represent evidence of incidental burning on the midden during the course of the Caddo occupation, perhaps to reduce the odor of decaying plant and animal remains in the midden. No daub was recovered in the midden investigations, suggesting that any structure that may have stood in the vicinity of the midden had not been burned before or after it was abandoned.

The 22 pieces of lithic debris are all small, non-cortical pressure and retouch flakes from the final manufacture of stone tools, probably produced during the manufacture of arrow points and/or flake tools. A wide variety of lithic raw materials are represented in the lithic debris, including chert (64\%), novaculite (23\%), quartzite $(4.5 \%)$, petrified wood $(4.5 \%)$, and ferruginous sandstone $(4.5 \%)$. The cherts are primarily gray in color $(n=11)$, along with red $(n=1)$ and brown $(n=2)$. These materials may have been gathered from river gravel along the nearby Neches River, as beds of chert gravel that may be the source of this knappable material have been reported in the vicinity of the dam at Lake Palestine on the Neches River. The novaculite is gray $(n=3)$ and dark gray $(n=2)$ in color. This material could have been obtained in Red River gravels in northeastern Texas, or from Bowie gravels along the stream divide between the Red and Sulphur rivers. Nevertheless, this material is not locally available, but would have been brought from a considerable distance to the site. The other raw materials - quartzite, petrified wood, and ferruginous sandstone - are locally available in gravels

FAUNAL REMAINS FROM THE LANG PASTURE (41AN38) 
by LeeAnna Schniebs

Investigations in the Lang Pasture area at 41AN38 yielded 118 faunal specimens. These fragments were recovered from five shovel tests and a $50 \times 50 \mathrm{~cm}$ unit (ST 7), and depths range from 0-63 cm bs. The purpose of the faunal analysis is to determine the animal subsistence practices of the Caddo residents of the site, including the utilization of available natural resources of the area. The methodology employed in this analysis has been spelled out in detail in Schniebs (2005:347-348). The complete inventory of the faunal sample can be found in Table 2.

The identifiable vertebrate taxa include reptile and mammal. Number of identified specimens (NISP) and minimum number of individuals (MNI) for each taxon are summarized in Table 3, as are weights for each taxon and approximate percentages of the assemblage. Composition of the anatomical elements for each taxon can be found in Table 4.

\section{Class Reptilia}

Order Testudinata (Family indeterminate): Unidentifiable turtle is represented by three small shell fragments. They were recovered from three levels in ST 7. It is likely that they are musk/mud or box turtle, based on size. Turtles are dietary supplements often found in archeological contexts. They are easily procured and usually readily available. One fragment is burned.

Order Testudinata, Family Emydidae: Box turtle (Terrapene sp.) is represented by two shell fragments, recovered from two levels in ST 7. One piece is burned. The three-toed box turtle (T. carolina) prefers woodlands and thickets, and the ornate box turtle ( $T$. ornata) occurs in open, treeless areas; these are dry-land turtles that close their shells tightly when danger threatens (Conant 1975).

\section{Class Mammalia}

Order Marsupialia, Family Didelphidae: Virginia opossum (Didelphis virginiana) is represented by a mandible fragment with three broken teeth in socket. It was recovered from ST 7 at 40-50 cm bs. The opossum is widespread throughout eastern Texas, and probably occur in every county; next to the raccoon, opossums are probably the most common medium-sized mammal in eastern Texas (Schmidly 1983). Sometimes it is hunted for sport, especially in the South, but the edible meat is oily (Burt and Grossenheider 1980).

Order Lagomorpha, Family Leporidae: Rabbit is represented by one burned femur fragment recovered from ST 7 at 30-40 cm bs. Fragmentation prevented specific identification, although it compares favorably in size to swamp rabbit. Two species of cottontail inhabit the area: the Eastern cottontail (Sylvilagus floridanus) prefers heavy brush, strips of forest with open areas, edges of swamps, and weed patches; swamp rabbit (Sylvilagus aquaticus) prefers swamps, marshes, and wet bottomlands (Burt and Grossenheider 1980). Osteologically, the swamp rabbit is the largest of the cottontails within its range (Davis 1978). It is unlikely the remains of jackrabbit (Lepus californicus) because its range borders on the extreme southern edge of Anderson County. Rabbits are easily procured by hunters and frequently found in Caddo faunal assemblages.

The Eastern cottontail occurs throughout eastern Texas in all vegetational regions and in all habitats except the aquatic ones. In the forested Pineywoods region, the swamp rabbit is usually more common than any other lagomorph in second-growth timber over twelve years old (Schmidly 1983). 
Table 2. Complete Inventory of Faunal Specimens from the Lang Pasture (41AN38) Site.

\begin{tabular}{|c|c|c|c|c|c|c|c|c|c|c|c|}
\hline & & & & & & & & & & & \\
\hline ST No. & $\begin{array}{l}\text { Depth, } \\
\mathrm{cm} \text { bs }\end{array}$ & Qty & Taxon & Element/Portion & Side & Age & Taph. & Burn & Gnaw & $\mathrm{Wt} / \mathrm{g}$ & Comments \\
\hline 1 & 0to20 & 2 & med mam & unid & & & none & wh & & 0.5 & \\
\hline 1 & 20 to 40 & 1 & $\lg$ mam & unid & & & none & blk & & 2.1 & \\
\hline 1 & 20 to 40 & 1 & lg mam & 1.b.frag & & & none & not & & 2.9 & spir frac \\
\hline 1 & 20 to 40 & 1 & $\lg$ mam & 1.b.frag & & & none & not & & 1.5 & \\
\hline 1 & 20 to 40 & 2 & med mam & 1.b.frag & & & none & wh & & 0.4 & \\
\hline 1 & 20 to 40 & 2 & med mam & unid & & & none & wh & & 0.3 & \\
\hline 1 & 20 to 40 & 1 & unid & unid & & & none & not & & 0.3 & poss fish \\
\hline 1 & 40 to60 & 1 & deer & tib crest & $\mathrm{R}$ & & exfol & not & & 4.9 & \\
\hline 1 & 40 to60 & 1 & med mam & unid & & & none & wh & & 0.2 & \\
\hline 2 & 0 to 20 & 1 & $\lg$ mam & 1.b.frag & & & none & wh & & 0.1 & \\
\hline 2 & 20 to 40 & 1 & deer & ulna shft frg & & & none & not & & 0.3 & \\
\hline 2 & 20 to 40 & 1 & deer & antler frg & & & none & wh & & 0.2 & \\
\hline 3 & 0to20 & 1 & deer & mtpod shft frg & & & none & wh & & 0.5 & \\
\hline 3 & 20 to 40 & 1 & deer & phx2 dist & $\mathrm{R}$ & & none & wh & & 1 & spir frac \\
\hline 3 & 20 to 40 & 1 & $\lg$ mam & 1.b.frag & & & none & wh & & 0.4 & \\
\hline 3 & 20 to 40 & 2 & med mam & unid & & & none & not & & 0.6 & \\
\hline 4 & 20 to 40 & 1 & $\lg$ mam & 1.b.frag & & & exfol & not & & 1.8 & \\
\hline 4 & 20 to 40 & 1 & med mam & unid & & & none & wh & & 0.1 & \\
\hline 4 & 20 to 40 & 2 & sm mam & unid & & & none & wh & & 0.1 & \\
\hline 5 & 0 to 20 & 1 & $\lg$ mam & 1.b.frag & & & none & not & rodent & 2.6 & \\
\hline 5 & 0 to 20 & 2 & lg mam & 1.b.frag & & & none & wh & & 0.7 & \\
\hline 5 & 20 to 40 & 1 & lg mam & 1.b.frag & & & none & wh & & 0.2 & \\
\hline 7 & 0 to10 & 1 & $\lg$ mam & unid & & & none & char & & 0.2 & \\
\hline 7 & 0 to10 & 1 & $\lg$ mam & unid & & & none & not & & 0.3 & \\
\hline 7 & 0 to10 & 7 & lg mam & unid & & & none & wh & & 1 & \\
\hline 7 & 10 to 20 & 1 & $\lg$ mam & 1.b.frag & & & none & wh & & 0.2 & \\
\hline 7 & 10 to 20 & 2 & med mam & unid & & & none & not & & 0.3 & \\
\hline 7 & 10 to 20 & 3 & med mam & unid & & & none & wh & & 0.3 & \\
\hline 7 & 10 to 20 & 1 & sm mam & unid & & & none & not & rodent & 0.1 & \\
\hline 7 & 10 to 20 & 1 & turtle & shell frg & & & none & not & & 0.2 & prob box \\
\hline 7 & 20 to 30 & 1 & box turtle & neural & A & & none & char & & 0.3 & \\
\hline 7 & 20 to 30 & 6 & $\lg$ mam & unid & & & none & wh & & 1.2 & \\
\hline 7 & 20 to 30 & 1 & med mam & unid & & & none & not & & 0.4 & \\
\hline 7 & 20 to 30 & 1 & turtle & shell frg & & & none & not & & 0.1 & \\
\hline 7 & 30 to 40 & 1 & box turtle & peripheral frg & & & none & not & & 0.1 & \\
\hline 7 & 30 to 40 & 1 & deer & mttar dx & $\mathrm{R}$ & imm & none & not & & 11.7 & \\
\hline 7 & 30 to 40 & 1 & deer & petrous & $\mathrm{R}$ & & none & not & & 6.7 & \\
\hline 7 & 30 to 40 & 1 & lg mam & unid & & & none & blk & & 0.3 & \\
\hline 7 & 30 to 40 & 4 & $\lg \mathrm{mam}$ & 1.b.frag & & & none & wh & & 1.5 & \\
\hline 7 & 30 to 40 & 1 & lg mam & unid & & & none & wh & & 0.4 & \\
\hline 7 & 30 to 40 & 1 & med mam & unid & & & none & not & & 0.6 & \\
\hline 7 & 30 to 40 & 1 & rabbit & fem dist frg & & & none & wh & & 0.2 & prob swamp \\
\hline 7 & 30 to 40 & 1 & sm mam & unid & & & none & not & & 0.2 & \\
\hline 7 & 30 to 40 & 6 & sm mam & unid & & & none & wh & & 0.6 & \\
\hline 7 & 30 to 40 & 1 & turtle & shell frg & & & none & wh & & 0.1 & \\
\hline 7 & 40 to 50 & 2 & $\lg$ mam & 1.b.frag & & & none & blk & & 0.7 & \\
\hline 7 & 40 to50 & 1 & lg mam & 1.b.frag & & & abraded & not & rodent & 0.6 & \\
\hline 7 & 40 to50 & 2 & lg mam & unid & & & exfol & not & & 2 & \\
\hline 7 & 40 to50 & 1 & $\lg$ mam & 1.b.frag & & & none & wh & & 0.8 & spir frac \\
\hline
\end{tabular}




\begin{tabular}{|c|c|c|c|c|c|c|c|c|c|c|}
\hline & $40 \operatorname{to} 50$ & 6 & $\lg$ mam & unid & & none & wh & & 1.6 & \\
\hline 7 & 40 to50 & 1 & med mam & unid & & none & not & & 0.3 & \\
\hline 7 & 40 to50 & 3 & med mam & unid & & none & wh & & 0.4 & \\
\hline 7 & 40 to50 & 1 & opossum & mand t'row & $\mathrm{L}$ & exfol & not & & 1.4 & inc I,P3,P4 frg \\
\hline 7 & 40 to50 & 2 & sm mam & unid & & none & wh & & 0.1 & \\
\hline 7 & 50 to58 & 1 & $\lg$ mam & unid & & abraded & not & rodent & 2 & Stain 2 \\
\hline 7 & $50 \operatorname{to} 58$ & 1 & med mam & unid & & none & wh & & 0.1 & Stain 2 \\
\hline 7 & 50 to58 & 2 & sm mam & unid & & none & not & & 0.1 & Stain 2 \\
\hline 7 & 50 to58 & 9 & sm mam & unid & & none & wh & & 0.2 & Stain 2 \\
\hline 7 & 50 to63 & 2 & $\lg$ mam & 1.b.frag & & none & wh & & 0.4 & spir frac; Stain 1 \\
\hline 7 & 50to63 & 1 & med mam & unid & & none & wh & & 0.1 & Stain 1 \\
\hline 7 & 50to63 & 10 & sm mam & unid & & none & wh & & 0.1 & Stain 1 \\
\hline
\end{tabular}

Table 3. Taxonomic Composition of Lang Pasture (41AN38) Faunal Sample.

\begin{tabular}{|l|l|r|r|r|r|}
\hline & & & & \\
\hline Scientific Name & $\begin{array}{l}\text { Common } \\
\text { Name }\end{array}$ & NISP & MNI & \% of Site & Wt/g \\
\hline $\begin{array}{l}\text { Vertebrata } \\
\text { (indeterminate) }\end{array}$ & unidentifiable & 1 & & 1 & 0.3 \\
\hline Testudinata & turtle & 3 & & 3 & 0.4 \\
\hline Terrapene sp. & box turtle & 2 & 1 & 2 & 0.4 \\
\hline Mammalia (small) & sm. mammal & 33 & & 28 & 1.5 \\
\hline Mammalia (medium) & med. mammal & 23 & & 19 & 4.6 \\
\hline Mammalia (large) & Ig. mammal & 47 & & 39 & 25.5 \\
\hline Didelphis virginiana & opossum & 1 & 1 & 1 & 1.4 \\
\hline Leporidae & rabbit & 1 & 1 & 1 & 0.2 \\
\hline Odocoileus virginianus & White-tailed & 7 & 1 & 6 & 25.3 \\
& deer & & & & 100 \\
\hline & TOTAL & 118 & 4 & 59.6 \\
\hline
\end{tabular}

Order Artiodactyla, Family Cervidae: Whitetail Deer (Odocoileus virginianus) is represented by seven fragments, including the remains of one immature individual. They were recovered from three levels in four shovel tests, and three pieces are burned. Deer are found in suitable brushy or wooded country throughout the state (Davis 1978). They occur in all vegetal regions, but in eastern Texas they are found in larger numbers in timbered areas (Schmidly 1983). Deer is the most common large game animal preferred by the Caddo, and also one of their main subsistence animals. The Caddo were adept imitators of deer, and a hunter disguised with the antlers and hide of a deer was able to approach his quarry closely, and even to attract it to himself (Newcomb 1993).

Unidentifiable large mammal bone fragments dominate the faunal sample $(n=47,39 \%)$, and these are most likely the remains of deer. Unidentifiable small mammal bones are also plentiful ( $n=33,28 \%)$. These could be the remains of rabbit as well as possible squirrel. Squirrel is another small animal common in Caddo faunal assemblages. The unidentifiable medium mammal $(n=23,19 \%)$ could be opossum, raccoon, or the remains of immature deer.

The faunal collection from the Lang pasture area at 41AN38 is generally well-preserved, but fragmented. Tapho- 


\begin{tabular}{|c|c|c|c|c|c|c|}
\hline $\begin{array}{l}\text { Table 4. Composition of } \\
\text { Elements. }\end{array}$ & ang Pasture (41 & N38) Faun: & & & & \\
\hline & & & & & & \\
\hline Scientific Name & $\begin{array}{l}\text { Common } \\
\text { Name }\end{array}$ & Element & & & & \\
\hline & & unid & cranial & \begin{tabular}{|l|} 
long \\
bone
\end{tabular} & phalanx & other \\
\hline $\begin{array}{l}\text { Vertebrata } \\
\text { (indeterminate) }\end{array}$ & unidentifiable & 1 & & & & \\
\hline Testudinata & turtle & & & & & 3 \\
\hline Terrapene sp. & box turtle & & & & & 2 \\
\hline Mammalia (small) & sm. mammal & 33 & & & & \\
\hline Mammalia (medium) & med. mammal & 21 & & 2 & & \\
\hline Mammalia (large) & lg. mammal & 27 & & 20 & & \\
\hline Didelphis virginiana & opossum & & 1 & & & \\
\hline Leporidae & rabbit & & & 1 & & \\
\hline Odocoileus virginianus & $\begin{array}{l}\text { White-tailed } \\
\text { deer }\end{array}$ & & 1 & 4 & 1 & 1 \\
\hline & TOTAL & 82 & 2 & 27 & 1 & 6 \\
\hline & & & & & & \\
\hline NOTE: & & & & & & \\
\hline $\begin{array}{l}\text { "Cranial" inc. one petrol } \\
\text { in socket. }\end{array}$ & and a mandib & ragment v & vith teeth $f$ & fragments & & \\
\hline $\begin{array}{l}\text { "Long Bone" inc. tibia, L } \\
\text { fragments. }\end{array}$ & a, metapodial, & $\mathrm{d}$ femur fr & agments a & as well as $i$ & determin & nate shaft \\
\hline "Other" inc. shell and ar & er fragments. & & & & & \\
\hline & & & & & & \\
\hline
\end{tabular}

nomic patterns are absent on most of the collection, although several pieces are exfoliated or abraded. Eightynine specimens are burned (Table 5), probably the result of trash disposal rather than cooking or catastrophic events. Four large mammal long bone fragments and the deer toe are spirally fractured, possible evidence of human impact. Three large mammal bones and one small mammal bone are slightly rodent gnawed.

The majority of bone fragments were recovered from ST 7 (n=90). Quantities from the other shovel tests range from three to 12 specimens each (see Table 1).

The faunal sample from the Lang Pasture area at 41AN38 is a typical Caddo collection. It provides a sketchy view of dietary preferences that appear to be comprised of, but not limited to, deer, rabbit, and turtle. The Caddo undoubtedly utilized much more of the rich animal resources available in East Texas than is reflected in this small faunal assemblage.

\section{SUMMARY AND CONCLUSIONS}

There is a well-preserved Caddo midden deposit on the Lang Pasture site (41AN38), located on private prop- 


\begin{tabular}{|c|c|c|c|c|c|}
\hline \multicolumn{5}{|c|}{$\begin{array}{l}\text { Table 5. Summary of Burned Faunal Specimens from Lang Pasture } \\
\text { (41AN38). }\end{array}$} & \\
\hline \multirow{3}{*}{ Scientific Name } & \multirow{3}{*}{$\begin{array}{l}\text { Common } \\
\text { Name }\end{array}$} & \multirow{2}{*}{\multicolumn{2}{|c|}{ Degree of Burning }} & \multirow[b]{3}{*}{ black } & \multirow[b]{3}{*}{ white } \\
\hline & & & & & \\
\hline & & $\begin{array}{l}\text { not } \\
\text { burned }\end{array}$ & charred & & \\
\hline $\begin{array}{l}\text { Vertebrata } \\
\text { (indeterminate) }\end{array}$ & unidentifiable & 1 & & & \\
\hline Testudinata & turtle & 2 & & & 1 \\
\hline Terrapene sp. & box turtle & 1 & 1 & & \\
\hline Mammalia (small) & sm. mammal & 4 & & & 29 \\
\hline Mammalia (medium) & med. mammal & 7 & & & 16 \\
\hline Mammalia (large) & lg. mammal & 9 & 1 & 4 & 33 \\
\hline Didelphis virginiana & opossum & 1 & & & \\
\hline Leporidae & rabbit & & & & 1 \\
\hline Odocoileus virginianus & $\begin{array}{l}\text { White-tailed } \\
\text { deer }\end{array}$ & 4 & & & 3 \\
\hline & TOTAL & 29 & 2 & 4 & 83 \\
\hline & & & & & \\
\hline
\end{tabular}

erty less than $15 \mathrm{~m}$ west from the SH 155 right-of-way fence. The right-of-way was the scene of intensive Texas Department of Transportation-sponsored excavations in the spring of 2006 (Kelley et al. 2006). In an effort to better understand the contents and character of the midden deposits, by themselves and by how they may relate to the features and archeological deposits from the Lang Pasture site (41AN38) in the right-of-way, six shovel tests and one 50 x $50 \mathrm{~cm}$ unit were excavated in and adjacent to the midden in March 2006. The midden feature turned out to be approximately $10 \mathrm{~m}$ in diameter and ca. $23-40 \mathrm{~cm}$ in thickness, and there were pit and post hole features preserved below the midden in ST 7, suggesting it might have accumulated in the area of an abandoned Caddo structure. Animal bones and charred plant remains are preserved in the midden as well.

Although no radiocarbon dates have been obtained on samples from the midden (there are charred nutshells from Stains 1 and 2 in ST 7 that could be suitable for dating), the recovery of both Poynor Engraved and Patton Engraved in the decorated sherds-as well as a low P/DR value of 0.88 , falling in Group II of the provisional seriation of Late Caddo components (Frankston phase) in this part of the upper Neches River basin (Perttula et al. 2005: Table 1)—strongly suggests that the midden began to accumulate sometime after ca. A. D. 1450. Poynor Engraved was made by Caddo potters from ca. A.D. 1400-1650 (and later), indicating the broad range of time in which the midden may have been used. The one post-A.D. 1650 Patton Engraved sherd from the top of the midden also implies a very late protohistoric use of the midden area, although not necessarily leading to any midden accumulation at that time; Patton Engraved sherds have also been found in low numbers at 41AN38 in the SH 155 right-of-way deposits (Kelley et al. 2006).

Analysis of the recovered material culture remains from the SH 155 right-of-way archeological deposits, in combination with radiocarbon and TL dates from the area, should permit a more refined consideration of the temporal and spatial associations between the Lang Pasture (41AN38) midden deposits and the features and artifacts recovered from the site in the Texas Department of Transportation right-of-way. Those analyses are now underway. 


\section{ACKNOWLEDGMENTS}

I would like to thank Bo Nelson and Mark Walters, who volunteered their time to investigate the 41AN38 midden deposits that they observed across the project right-of-way fence. No Texas Department of Transportation monies were spent in carrying out these investigations, or in the writing up of the results of their work as presented here. Bobby Gonzalez (Caddo Nation of Oklahoma) drew the decorated sherds in this article. LeeAnna Schniebs (Archaeofaunas) completed the faunal analysis. Finally, I thank the landowner, Mr. Earl Lang, for permission to carry out this work.

\section{REFERENCES CITED}

Burt, W. H. and R. P. Grossenheider

1980 A Field Guide to the Mammals. Peterson Field Guide Series. 3rd Edition. Houghton Mifflin Co., Boston.

Conant, R.

1975 A Field Guide to Reptiles and Amphibians of Eastern and Central North America. 2nd Edition. Peterson Field Guide Series. Houghton Mifflin Co., Boston.

Davis, W. B.

1978 The Mammals of Texas. Bulletin No. 41, revised. Texas Parks and Wildlife Department, Austin.

Kelley, D. B., T. K. Perttula, B. Nelson, D. G. Hunter, B. M. Albert, J. Kelly, and D. E. Wilson

2006 Interim Report on Archeological Data Recovery at 41AN38, Anderson County, Texas. Coastal Environments, Inc., Baton Rouge.

Kleinschmidt, U. K. W.

1982 Review and Analysis of the A. C. Saunders Site, 41AN19, Anderson County, Texas. Master's thesis, Department of Anthropology, The University of Texas at Austin.

Newcomb, W.W., Jr.

1993 The Indians of Texas from Prehistoric to Modern Times. 2nd Edition. University of Texas Press, Austin.

Perttula, T. K., D. B. Kelley, D. E. Wilson, and B. M. Albert

2005 Research Design and Scope of Work for Data Recovery Excavations at 41AN38, Anderson County, Texas. Coastal Environments, Inc., Baton Rouge.

Schmidly, D. J.

1983 Texas Mammals East of the Balcones Fault Zone. Texas A\&M University Press, College Station.

Schniebs, L.

2005 Analyses of the Faunal Remains from Residential and Mound Areas. In Archeological Investigations at the Pilgrim's Pride Site (41CP304), a Titus Phase Community in the Big Cypress Creek Basin, Camp County, Texas, edited by T. K. Perttula, pp. 347-356. 2 Vols. Report of Investigations No. 30. Archeological \& Environmental Consultants, LLC, Austin. 